\title{
Fe Alloys: Production and Metallurgical Aspects: Part I
}

\author{
DEAN GREGUREK, ${ }^{1,5}$ ZHIWEI PENG,${ }^{2,6}$ CHRISTINE WENZL, ${ }^{3,7}$ \\ and JESSE F. WHITE ${ }^{4,8}$ \\ 1.-Technology Center Leoben, RHI AG, Magnesitstrasse 2, 8700 Leoben, Austria. 2.-School of \\ Minerals Processing and Bioengineering, Central South University, Changsha 410083, Hunan, \\ China. 3.-RHI AG, Wienerbergstrasse 9, 1100 Vienna, Austria. 4.-Elkem Carbon AS, NO-4675, \\ Kristiansand, Norway. 5.-e-mail: dean.gregurek@rhi-ag.com. 6.-e-mail: zwpeng@csu.edu.cn. \\ 7.—e-mail: christine.wenzl@rhi-ag.com. 8.—e-mail: jesse.white@elkem.no
}

Ferroalloys are closely linked to steel production: only with the addition of ferroalloys can special steels be produced with specific properties for even the most challenging applications. Therefore, the production quantities of ferroalloys are tightly linked to steel production scale. The development and manufacturing of high-tech steels require highpurity additives that can be added in a controlled and very precise manner. Hence, further improvement of ferroalloy production processes is required and a topic of ongoing research on industrial and academic levels to meet the demands of the steel producers and simultaneously allow for efficient and economic ferroalloy production.

The present topic "Fe Alloys: Production and Metallurgical Aspects" aims to provide JOM readers with interesting reading material and updates. The importance of the present topic also became apparent in the volume of papers submitted. Due to the large number of high-quality papers submitted, the topic has been split into two parts, this being part one, with the second part following in February 2017.

In ilmenite smelting, the aim is not the production of a ferroalloy, even though metallic iron is produced, but the main purpose is to remove the $\mathrm{Fe}$ from the slag, which is mainly a mixture of $\mathrm{Fe}$ and Ti oxides. Only after Fe removal can the remaining Ti oxide slag fit the subsequent (white) pigment production. The first article "Study of Porosity on Titania Slag Obtained by Conventional Sintering and Thermal Plasma Process" by Sneha Samal investigates the development of porosity in ilmenite during sintering via conventional and thermal plasma heating. The physical dimensions and

Dean Gregurek, Zhiwei Peng, and Jesse White are the JOM advisors for the Pyrometallurgy Committee of the TMS Extraction \& Processing Division, and guest editors for the topic Fe Alloys: Production and Metallurgical Aspects: Part I in this issue. morphology of the pores were characterized with regards to the area fraction, mean diameter, shape factor, and elongation factor. Under both conventional and thermal plasma heating conditions, porosity developed on the surface of ilmenite. The two sintered ilmenite materials showed differences in morphology and porosity. A lower porosity was observed in the plasma-sintered sample when compared with that obtained via conventional heating.

The standard rotary kiln-electric furnace (RKEF) production route is a well-established and the most common approach for ferronickel production despite high energy consumption. Xiaodong $\mathrm{Ma}$ et al. investigated a possible improvement in $\mathrm{FeNi}$ production in their article "Efficient Utilization of Nickel Laterite to Produce Master Alloy". They describe a novel process for the smelting reduction of laterite at a lower temperature by the addition of $\mathrm{Mo} / \mathrm{MoO}_{3}$. This results in a more effective metal-slag separation and a reduction of the smelting temperature by at least $100 \mathrm{~K}$ for the electric furnace process. The addition of $\mathrm{Mo} / \mathrm{MoO}_{3}$ decreased the melting point of ferronickel alloys. Meanwhile, Mo served as a collector to aggregate the ferronickel sponges for better metal-slag separation.

Also the next article, "Phase Evolution and Ni-Fe Granular Growth of Saprolitic Laterite Ore-CaO Mixtures During Reductive Roasting” by Jun Luo et al. deals with improvements in FeNi production, namely the correlation between phase evolution, fusion behavior and growth of $\mathrm{Ni}-\mathrm{Fe}$ granules in laterite ore/ $\mathrm{CaO}$ mixtures during reductive roasting. It was found that the fusion behaviors and the granule growth are closely related to the contents of $\mathrm{CaO}$ and $\mathrm{FeO}$, as well as the $\mathrm{CO}$ partial pressure in the gas mixture.

Slag properties are a vital factor for furnace operation as they influence, for example, tapping, metal/slag separation, operating temperature and refractory corrosion. Therefore, Christoph Sagadin 
et al. investigated the melting behavior of $\mathrm{FeNi}$ slags in electric furnaces in the article "Melting Behavior of Ferronickel Slags". Especially, the enormously large slag amounts, their acidic character and high melting temperatures pose challenges for the ferronickel and refractory producers. The main focus of this work was to achieve an improved understanding of FeNi slags in the electric furnace, namely both their melting behavior and influence on refractory corrosion.

In all pyrometallurgical processes, especially high-temperature ferroalloy production processes, refractories are a decisive factor for smooth furnace operation. Careful selection of proper refractory qualities and functional lining design are particularly important in new processes and furnace types. The next article "Refractory Corrosion Mechanisms in a Novel High Carbon Ferromanganese Production Furnace" by Dean Gregurek et al. presents the refractory design for a novel HCFeMn smelting furnace that-other than standard submerged arc furnaces-allows the processing of fine ores. Postmortem investigations of selected refractory samples such as basic and non-basic bricks, castables and ramming materials installed in the furnace provide valuable information about the main wear mechanisms. Additionally, the process slag and metal were investigated both practically and theoretically by using thermodynamic calculations, to better understand the corrosion phenomena observed in the post-mortem samples.

The following papers being published under the topic of $\mathrm{Fe}$ Alloys: Production and Metallurgical Aspects: Part I provide excellent details and research on the subject. To download any of the papers, follow the url http://link.springer.com/jour nal/11837/68/12/page/1 to the table of contents page for the December 2016 issue (vol. 68, no. 12).

- "Study of Porosity on Sintered Ilmenite Using Conventional Furnace and Thermal Plasma Process" by Sneha Samal.

- "Efficient Utilization of Nickel Laterite to Produce Master Alloy" by Xiaodong Ma, Zhixiang Cui, and Baojun Zhao.

- "Phase Evolution and Ni-Fe Granular Growth of CaO-mixed Saprolitic Laterite During Reductive Roasting" by Jun Luo, Guanghui Li, Zhiwei Peng, Mingjun Rao, Yuanbo Zhang, and Tao Jiang.

- "Melting Behaviour of Ferronickel Slags" by Christoph Sagadin, Stefan Luidold, Christoph Wagner, and Christine Wenzl.

- "Refractory Corrosion Mechanisms in a Novel HighCarbon Ferromanganese Production Furnace" by D. Gregurek, C. Wenzl, D. Kreuzer, A. Spanring, M. Kirschen, D. Zeele, and J. Groenewald. 